San Jose State University

SJSU ScholarWorks

Master's Theses

Master's Theses and Graduate Research

2006

\title{
Genetic characterization of four populations in two subspecies of spotted owl
}

Tonja Y. Chi

San Jose State University

Follow this and additional works at: https://scholarworks.sjsu.edu/etd_theses

\section{Recommended Citation}

Chi, Tonja Y., "Genetic characterization of four populations in two subspecies of spotted owl" (2006). Master's Theses. 2944.

DOI: https://doi.org/10.31979/etd.yu6j-pkzz

https://scholarworks.sjsu.edu/etd_theses/2944

This Thesis is brought to you for free and open access by the Master's Theses and Graduate Research at SJSU ScholarWorks. It has been accepted for inclusion in Master's Theses by an authorized administrator of SJSU ScholarWorks. For more information, please contact scholarworks@sjsu.edu. 


\title{
GENETIC CHARACTERIZATION OF FOUR POPULATIONS IN TWO SUBSPECIES OF SPOTTED OWL
}

\author{
A Thesis \\ Presented to \\ The Faculty of the Department of Biological Sciences \\ San José State University
}

In Partial Fulfillment

of the Requirements for the Degree

Master of Science

By

Tonja Y. Chi

August 2006 
UMI Number: 1438559

Copyright 2006 by

Chi, Tonja Y.

All rights reserved.

\section{INFORMATION TO USERS}

The quality of this reproduction is dependent upon the quality of the copy submitted. Broken or indistinct print, colored or poor quality illustrations and photographs, print bleed-through, substandard margins, and improper alignment can adversely affect reproduction.

In the unlikely event that the author did not send a complete manuscript and there are missing pages, these will be noted. Also, if unauthorized copyright material had to be removed, a note will indicate the deletion.

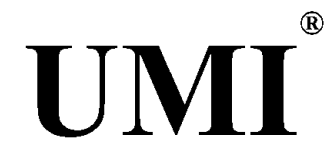

UMI Microform 1438559

Copyright 2007 by ProQuest Information and Learning Company.

All rights reserved. This microform edition is protected against unauthorized copying under Title 17, United States Code.

ProQuest Information and Learning Company

300 North Zeeb Road

P.O. Box 1346

Ann Arbor, MI 48106-1346 
(C) 2006

Tonja Y. Chi

ALL RIGHTS RESERVED 
APPROVED FOR THE DEPARTMENT OF BIOLOGICAL SCIENCES

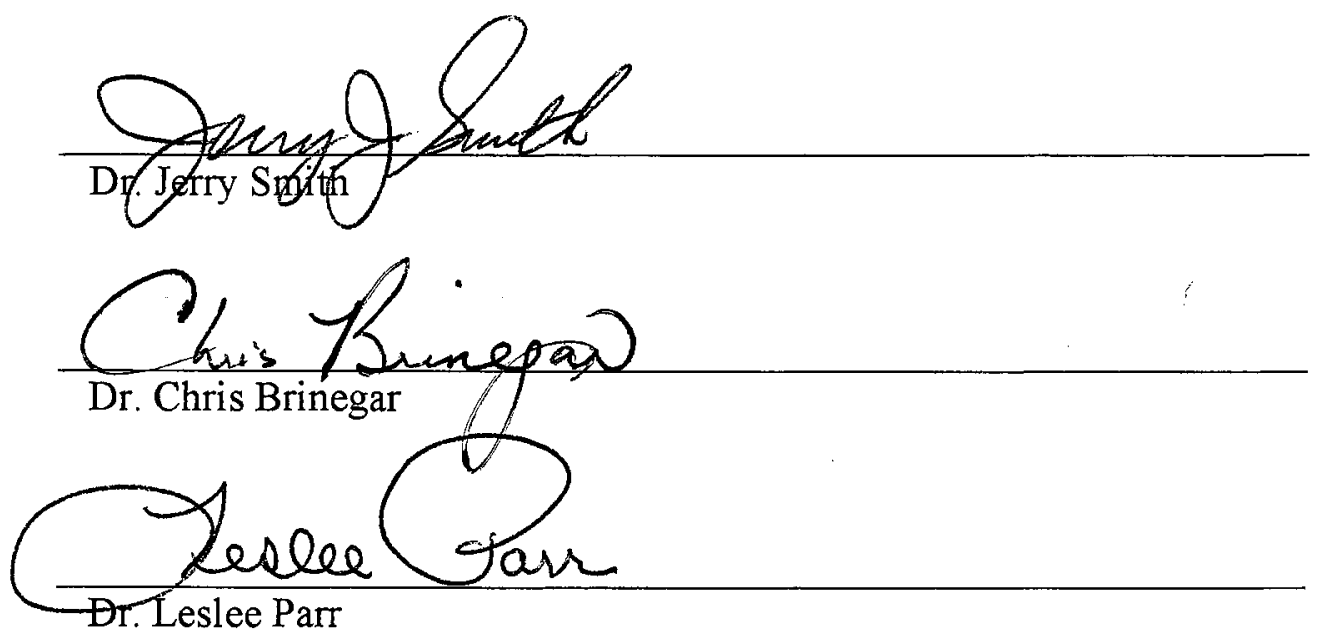

APPROVED FOR THE UNIVERSITY

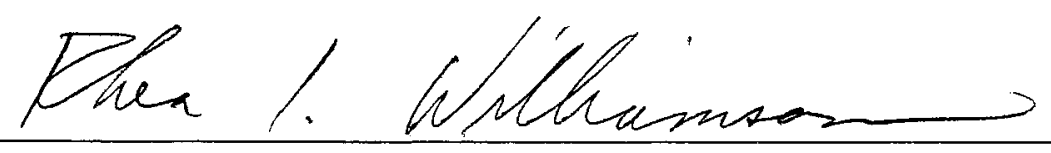




\section{ABSTRACT \\ GENETIC CHARACTERIZATION OF FOUR POPULATIONS IN TWO SUBSPECIES OF SPOTTED OWL}

\section{By Tonja Y. Chi}

The mitochondrial DNA control region from two populations each of California and Northern Spotted Owls was used to establish genetic composition for each population and determine genetic relationships within and among populations and subspecies (total $\mathrm{n}=91$ ). A neighbor-joining tree identified two distinct branches consistent with recognized subspecies. Seventeen haplotypes segregated as distinct sets for each subspecies, with one exception; the most common California haplotype was found in a single Northern Spotted Owl. An AMOVA found 81 percent variance between subspecies with only 2.7 percent within subspecies, signifying very low gene flow and definite genetic distinction between subspecies. Northern Spotted Owls had a higher amount of nucleotide and haplotype diversity than California Spotted Owls. Inland contiguous populations of each subspecies also had higher nucleotide and haplotype variability than isolated coastal populations. The coast California Spotted Owl populations constitute a separate ESU with low variation and small total numbers, likely warranting protection. 


\section{ACKNOWLEDGEMENTS}

This study has been made possible by support, determination, dedication, and cooperation from an army of exceptional people. The study was initiated and gained all of its momentum from the enthusiasm and motivation of Andrea Henke, who had a pure research vision, not only to contribute valuable information to the scientific community, but more importantly to benefit the success of the species. I deeply respect the work of my mentors and am immensely grateful for their biological expertise, time, energy, resources, and friendships: Andrea Henke, Jerry Smith, and Chris Brinegar. I thank my parents, Ben and Mary Chi, husband, Russ Biswell, and sisters, Danielle and Renee Chi, for their invaluable support. Finally I thank Leslee Parr, who provided useful comments on drafts of the thesis.

Many people and organizations provided important assistance. I thank Katherine Fehring, Daphne Hatch, and the National Park Service in Marin; Susan Yasuda and the El Dorado National Forest; Chris Hovnanian, Teryl Grubb, David Delaney, Rob Richardson, Chiree Keckler, and the Mendocino National Forest, U.S. Fish and Wildlife Service in Red Bluff, California; John Smiley and Big Creek Reserve; Denis Torio and Pico Blanco Camp.

Finally, I would like to thank the San José State University Department of Biological Sciences and funding made possible by the Arthur and Karin Nelson Scholarship and the Albert and Dorothy Ellis Research Fellowship. 


\section{TABLE OF CONTENTS}

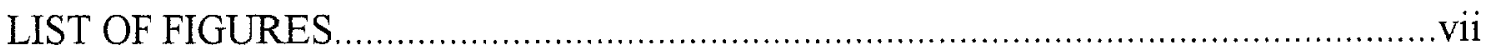

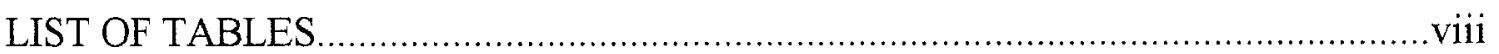

CHAPTERS

INTRODUCTION

METHODS

RESULTS

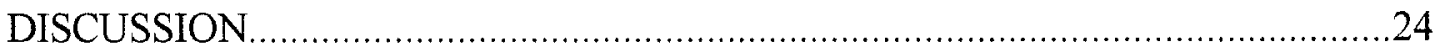

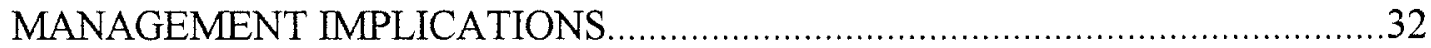

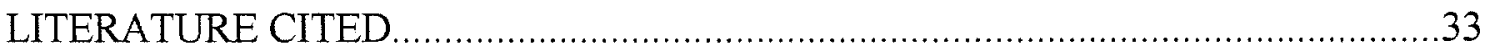




\section{LIST OF FIGURES}

FIGURE 1. Ranges of three subspecies of Spotted Owl........................................2

FIGURE 2. Northern and California Spotted Owl study locations.........................5

FIGURE 3. Kimura 2-Parameter Neighbor-Joining Tree with Bootstrap values...........15

FIGURE 4. Haplotype frequencies for four populations of Spotted Owls...................17

FIGURE 5. Mismatch distributions for three populations of Spotted Owls .................20 


\section{LIST OF TABLES}

Page(s)

TABLE 1. Estimates of mitochondrial DNA control region variability within each regional population and subspecies: number of individuals $(n)$, number of haplotypes $(n h)$, nucleotide diversity $(\pi)$, haplotype diversity $(h)$, and mean number of pairwise differences $(M P D)$.

TABLE 2. Distribution of the 17 observed control region haplotypes

from 91 Spotted Owls from four localities.

TABLE 3. Analysis of molecular variance (AMOVA) of California and Northern Spotted Owls.

TABLE 4. Spotted Owl Population pairwise $F_{S T}$ values (below diagonal), average pairwise differences within each population (diagonal), average pairwise differences between populations (above diagonal).

TABLE 5. Neutrality control region statistics within each regional population: Tajima's D (TD), Fu and Li's F* (no outgroup), Fu and Li's F (Barred Owl outgroup), $\mathrm{Fu}$ and Li's D* (no outgroup), Fu and Li's D (Barred Owl outgroup), Fu's $\mathrm{F}_{\mathrm{s}}$, Harpending's raggedness index ( $\mathrm{Hri}$ ). 


\section{INTRODUCTION}

Spotted Owls (Strix occidentalis) are monogamous, long-lived, territorial, nonmigratory birds that use a range of landscapes for nesting, roosting, and foraging,

including the complex multi-level, canopy coverage found in oak woodlands, redwood, and mixed conifer forests. They are sensitive to habitat alteration and predominantly subsist on small mammals such as woodrats, flying squirrels, rabbits, mice, and voles (Forsman et al. 1984), and less frequently on invertebrates and birds (Forsman et al. 1984, Young et al. 1997, Smith et al. 1999). Currently the Spotted Owl is recognized as consisting of three subspecies: Mexican Spotted Owl (S. o. lucida), Northern Spotted Owl (S. o. caurina), and California Spotted Owl (S. o. occidentalis). The Mexican Spotted Owl is found in Mexico and southwestern United States in parts of southern Utah, Arizona, New Mexico, and Colorado. The Northern Spotted Owl historically occupied the Pacific northwest from Canada (British Columbia) south into northern California. The California Spotted Owl range extends from the Pit River (in the Lassen region) of northeastern California through the Sierra Nevada Mountain range as far south as San Bernardino and San Jacinto, as well as coastal California from Monterey County south into Santa Barbara and portions of San Diego County (Gutiérrez et al. 1995) (Fig. 1). Both the Northern and Mexican Spotted Owl subspecies have been listed and protected as "Threatened Species" by the United States Fish and Wildlife Service (USFWS) and the Endangered Species Act since 1990 and 1993 (respectively). The California Spotted Owl was denied Federal listing by the USFWS in a 12-month finding 


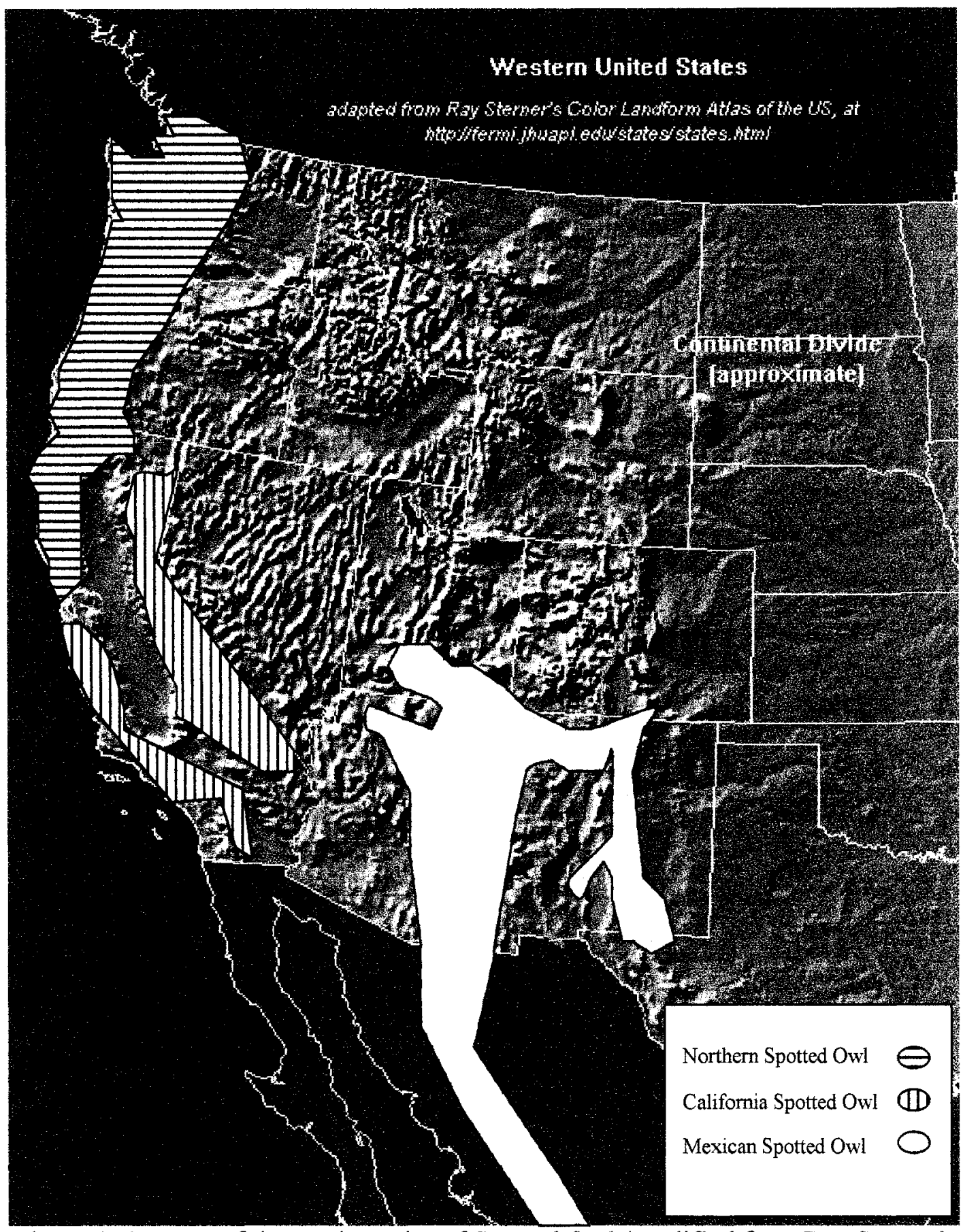

Figure 1. Ranges of three subspecies of Spotted Owl (modified from Ray Sterner's Color Landform Atlas of the United States). 
in 2003 (USDI 2003) primarily due to the existence of the Sierra Nevada Framework, a policy that limited logging and therefore protected California Spotted Owl habitat. However, in June 2005, in response to a filed petition, the USFWS determined that substantial evidence and current available data warranted a federal reexamination of the subspecies status as a potential threatened or endangered species. In May 2006, upon completion of the second 12-month finding, listing was again denied (USDI 2006).

The Northern Spotted Owl is a controversial high profile species and one of the most studied birds in the world due to their use of old growth habitat, a profitable and valuable timber source. Since the 1980's an abundance of information has been compiled regarding Spotted Owl biology and ecology including studies of habitat, demography, diet, behavior, and dispersal. More recently, the relative ease of DNA analysis techniques has initiated interest in Spotted Owl genetics. Population genetic analysis, when coupled with information regarding the life history of a species, is a powerful approach to understanding historic, current, and future population and evolutionary trends.

Spotted Owl genetic studies have used a variety of molecular markers such as allozymes (Barrowclough and Gutiérrez 1990), mitochondrial DNA (mtDNA) (Barrowclough and Groth 1999, Barrowclough et al. 1999, Haig et al. 2004a, Haig et al. 2004b), microsatellites (Thode et al. 2002, Henke 2005), AFLPs (Haig et al. 2004b), and RAPDs (Haig et al. 2001). Several of these studies have produced valuable information about the phylogeography of the species with sampling schemes extended throughout the 
entire geographic range with an emphasis on genetic structure and gene flow between subspecies (Barrowclough et al. 1999, Haig et al. 2004b, Barrowclough et al. 2005). All but one of these (Haig et al. 2004b) used only one type of molecular marker. Only intensive sampling of individuals within geographic locales can define and characterize the genetic health of regional populations and establish a baseline of genetic information. I intensively sampled two populations each of California and Northern Spotted Owls, one coastal and geographically isolated, and one inland and adjacent to neighboring populations (Fig. 2). These were the same populations and individuals Henke (2005) examined with microsatellite markers. One owl population had never been sampled before while the other three, had been represented in prior studies by only a few owl samples. I analyzed mtDNA and compared the results to Henke's microsatellite analysis (2005). Using multiple molecular markers provided substantial information from single individuals, while reducing the likelihood of potentially biased results since the two sets of data were generated by different mechanisms of inheritance. It is crucial for successful management of the species to define current genetic composition, identify historic relationships and population dynamics, and delineate any potential vulnerability to contemporary processes or future events. 


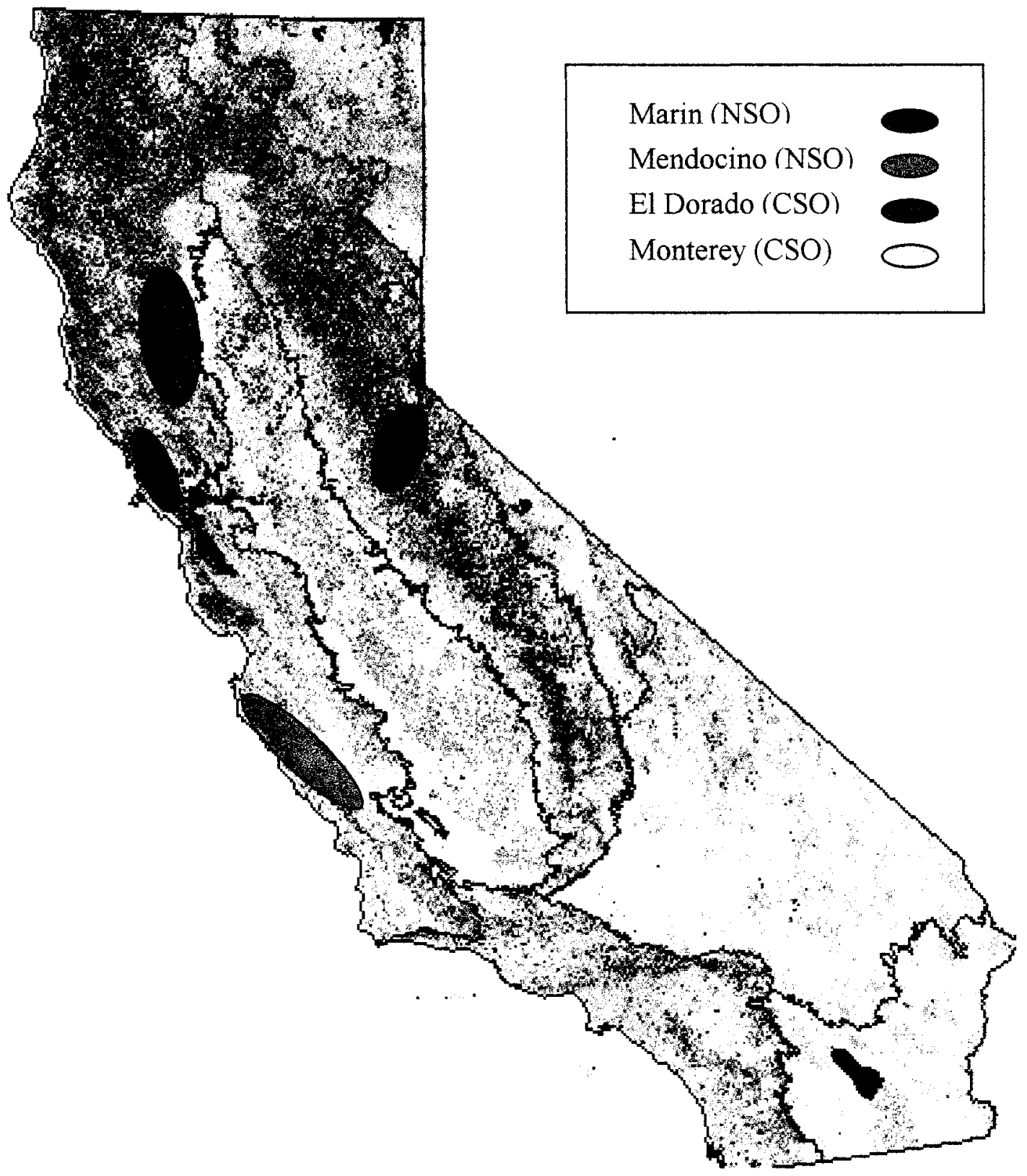

Figure 2. Northern and California Spotted Owl study locations (modified from Thematic Mapper Mosaic satellite data image of California, at http://www.biogeog.ucsb.edu/projects/gap/gap_proj.html). 


\section{METHODS}

Sampling

Ninety-one adult or juvenile owl mtDNA sequences were sampled from 77 Spotted Owl territories (male and female or male and juvenile individuals from the same families were used in some cases) throughout four California populations in 1999 - 2003 (Fig. 2): Marin County $(n=23)$, Mendocino National Forest $(n=25)$, El Dorado National Forest $(n=28)$, and Monterey County $(n=15)$. Genetic samples were collected from 88 known owl sites (Henke 2005), but I selected 77 sites evenly distributed throughout each region for this study. Spotted Owls were initially located by vocal territorial responses to the imitated four-note call performed during night surveys. When an owl response was detected, a compass bearing was recorded and the direction and distance noted. Often the owl would be visually located immediately and this area would be revisited during daylight hours to establish the presence or absence of an owl activity center. Feathers were obtained from the core nesting/roosting areas by visual sweeps in all of the populations except in Marin County where additional feathers were hand plucked during the banding process. The naturally shed or molted feather samples from the three other populations were from unbanded birds and were obtained by multiple visits to core territories during the nesting and breeding season. Feathers were easily identified as adult or juvenile early in the season based upon physical characteristics (Pyle 1997), carefully collected separately, stored in individual labeled envelopes to avoid cross-contamination, and kept at cool dry temperatures to limit DNA degradation and maintain integrity. 


\section{DNA Extraction}

In order to maximize quantities of DNA extracted from the calamus of the feather shaft, the PureGene Tissue DNA Isolation Kit protocol (Gentra Systems) was modified as follows: $0.3 \mathrm{ml}$ of cold cell lysis solution containing $20 \mathrm{mg} / \mathrm{ml}$ polyvinylpyrrolidone 40 (Sigma) was added to $1-2 \mathrm{~cm}$ of sliced (horizontal) calamus and ground for 2 min using a plastic pestle. Following the addition of $1.5 \mu \mathrm{lof} 20 \mathrm{mg} / \mathrm{ml}$ Proteinase $\mathrm{K}$, samples were incubated at $58^{\circ} \mathrm{C}$ for $3.5 \mathrm{~h}$ and $65^{\circ} \mathrm{C}$ for $15 \mathrm{~min}$, and then placed on ice. Samples were vortexed and incubated on ice for $30 \mathrm{~min}$ following the addition of $0.1 \mathrm{ml}$ cold protein precipitation solution. Supernatants were centrifuged for $10 \mathrm{~min}$ at $4^{\circ} \mathrm{C}$ and transferred to $1.5 \mathrm{ml}$ siliconized microfuge tubes. All pellets with the remnant feather material were stored at $-20^{\circ} \mathrm{C}$. Equal volumes of cold isopropanol and $1 \mu 1$ of $20 \mathrm{mg} / \mathrm{ml}$ glycogen were added to each sample. Tubes were inverted several times and stored overnight at $-20{ }^{\circ} \mathrm{C}$. DNA was centrifuged, washed with $70 \%$ ethanol, air-dried, and dissolved in 20 $\mu l$ of DNA hydration solution. In two instances where there were low concentrations or poor quality DNA samples, DNA was successfully re-extracted from the remnant feather material of previously extracted samples by repeating the same process described above, beginning with the addition of cold cell lysis solution.

Sex Protocol

Gender of the sample was determined by molecular analysis following a sexing protocol (a variation on Griffiths et al. 1998) or in rare cases identification was confirmed by actually witnessing the molt of the feather. Gender determination was accomplished 
using DNA amplification and subsequent enzyme restriction of the sex-linked CHD gene. Henke (2005) and I modified the Griffiths et al. (1998) protocol by altering both the forward and reverse primers for more consistent amplification of the CHD-W and CHD$\mathrm{Z}$ genes. All primers were prepared and obtained from Operon Biotechnologies (Alameda, CA). PCR reactions (20 $\mu$ l) contained 1X PCR Buffer (Applied Biosystems), 1.25 U AmpliTaq Gold DNA polymerase (Applied Biosystems), $0.3 \mathrm{mM}$ each dNTP, 2.5 mM MgCl 2 , and $0.75 \mu \mathrm{M}$ of each primer (P2Owl: 5'-ATCTCTGCATCRCTAAATCC3'; P8Owl: 5'-TCCCAAGGATGAGAAACTG-3'). An Eppendorf Mastercycler Gradient thermal cycler was used to perform the polymerase chain reaction as follows: $93^{\circ} \mathrm{C}$ for $9 \mathrm{~min}, 94^{\circ} \mathrm{C}$ for $30 \mathrm{sec}, 48^{\circ} \mathrm{C}$ for $45 \mathrm{sec}, 72^{\circ} \mathrm{C}$ for $1 \mathrm{~min}$, for a total of 35 cycles with a final extension of $72^{\circ} \mathrm{C}$ for 6 min. Products were restricted using HaeIII (Promega) to produce two bands for females (380 and $310 \mathrm{bp}$ ) or a single band (310 bp) for males, identified when electrophoresed on a $2.5 \%$ agarose gel in $1 \mathrm{X}$ TAE buffer and compared to DNA size markers (Promega).

PCR Amplification and Sequencing

PCR reactions were initially optimized using the N1 primer (5'AACATTGGTCTTGTAAGCCAA-3') for the light strand and the D20 primer (5'GTGATGGATCTTACTAACACC-3') for the heavy strand (Barrowclough et al. 1999). Due to variability in yields, I designed a new forward primer T1 (5'AACCCAACAAACACCTCACC-3') and optimized conditions to increase the quality and quantity of amplification. All primers were prepared and obtained from Operon 
Biotechnologies (Alameda, CA). PCR reactions ( $25 \mu 1)$ contained 1X PCR Buffer (Applied Biosystems), 1.25 U AmpliTaq Gold DNA polymerase (Applied Biosystems), $0.3 \mathrm{mM}$ each dNTP, $2.5 \mathrm{mM} \mathrm{MgCl}_{2}$, and $0.75 \mu \mathrm{M}$ of each primer. An Eppendorf Mastercycler Gradient thermal cycler was used to perform the polymerase chain reaction as follows: $95^{\circ} \mathrm{C}$ for $8 \mathrm{~min}, 95^{\circ} \mathrm{C}$ for $30 \mathrm{sec}, 54{ }^{\circ} \mathrm{C}$ for $1 \mathrm{~min}, 70^{\circ} \mathrm{C}$ for $2 \mathrm{~min}$, for a total of 36 cycles with a final extension of $70^{\circ} \mathrm{C}$ for $6 \mathrm{~min}$. The $788 \mathrm{bp}$ PCR products were electrophoretically quantified using DNA size markers (Promega) and 1.5\% agarose gels in 1X TAE buffer, pooled, and purified using DNA Minelute spin columns (Qiagen). A final quantification step was performed by electrophoretic comparison to the EZ Load Precision Molecular Mass Standard (BioRad).

DNA was sequenced by Sequetech (Mountain View, CA) in both the forward and reverse directions using BigDye v3.1 Terminator Cycle Sequencing technology and an Applied Biosystems Prism 3730 analyzer. The accuracy of all forward and reverse sequences was verified by alignment using either SEQUENCHER 4.1 or PAUP* $4.0 \mathrm{~b} 1$ (Swofford 2000). Analysis was performed on $567 \mathrm{bp}$ of the noncoding mtDNA control region, the most variable portion as shown by Barrowclough et al. (1999).

\section{Data Analysis}

CLUSTAL W Alignment Program was used to align a $567 \mathrm{bp}$ portion of all sample sequences. I evaluated phylogenetic relationships by generating a phylogenetic tree of all 91 individual sequences generated in MEGA Software 2.1 (Kumar et al. 2001) using a neighbor-joining tree making method, Kimura two-parameter distance model, and 
generating bootstrap values with 1000 replicates. Barred Owl sequences (Barrowclough et al. 1999) were used as outgroups.

Molecular diversity within and between populations and subspecies was evaluated in ARLEQUIN version 2.0 (Schneider et al. 2000) using standard measures including haplotype diversity $(h)$ and nucleotide diversity $(\pi)$. Nucleotide diversity is a function of average nucleotide differences between two randomly chosen sequences, number of individuals sampled, frequency of haplotypes, and the length of the sequence. ARLEQUIN version 2.0 (Schneider et al. 2000) used sum of squares to produce percent of variance and determined genetic differentiation for populations at individual, intraspecific, and interspecific levels using sequence divergence and frequency of haplotypes. Calculations for the analysis of molecular variance (AMOVA) using a hierarchical approach was based on estimated fixation indices derived from proportions of genetic differentiation based on interspecific $\left(\mathrm{F}_{\mathrm{ST}}\right)$, intraspecific $\left(\mathrm{F}_{\mathrm{SC}}\right)$, and individual $\left(\mathrm{F}_{\mathrm{CT}}\right)$ population differences with significance tests using 3024 permutations. Additionally genetic differentiation between populations was evaluated by pairwise $F_{\text {st }}$ values.

To interpret plausible historic population dynamics such as expansion, equilibrium, or decline, I used two approaches: mismatch distributions and Harpending's raggedness index (Hri). Both of these measures are based on sequence pairwise differences and frequency of segregating sites with the assumption of the infinite-sites model, no recombination, and coalescence theory. Harpending's raggedness index was a product of the significance of pairwise distribution values and was calculated using ARLEQUIN version 2.0 (Schneider et al. 2000). Harpending et al. (1993) identified a mean 
raggedness index greater than 0.06 to be consistent with historic populations stationary in size, and those less than 0.018 to be indicative of historic population expansion. Mismatch distributions calculated by DNASP version 4.10.3 (Rozas et al. 2003), determined the mean number of pairwise differences for each polymorphic population. Mismatch distributions show the relative frequencies of the average number of nucleotide site differences between pairs of individuals in a population. Resulting histograms expressing a smooth unimodal distribution are characteristic of historically expanding populations (Harpending 1994) and ragged multimodal distributions are consistent with constant population size and demographic equilibrium (Slatkin and Hudson 1991, Harpending et al. 1993).

Neutrality tests were performed by DNASP version 3 (Rozas and Rozas 1999) to evaluate departures from selective neutrality with Tajima's D, Fu and Li's F, F*, D, and $D^{*}$, and Fu's $F_{s}$ tests. The more recent version of DNASP version 4.10.3 (Rozas et al. 2003) was used to calculate one more neutrality test called the $R_{2}$ statistic. All neutrality tests do not have the same power to detect departures from neutrality caused by different evolutionary forces. Since the evolutionary mechanisms shaping each population are unknown, multiple tests of assumptions of neutrality were included in this analysis to increase the power of detection. These evaluate the selective or neutral evolutionary nature of a sequence where some are more sensitive to detecting neutrality deviations under different circumstances than others (Fu and Li 1993, Simonsen et al. 1995, Fu 1996, Fu 1997, Mousset et al. 2004, Sano and Tachida 2005). Departures from different neutrality tests could provide information about potential forces acting on each 
population. For example in computer simulations, Tajima's D test (Tajima 1989a) is more effective than $\mathrm{Fu}$ and Li's $\mathrm{F}, \mathrm{F}^{*}, \mathrm{D}$ and $\mathrm{D}^{*}$ tests at detecting hitchhiking, bottlenecks, and subdivision in populations larger than 50 (Simonsen et al. 1995). High values for Tajima's $D$ potentially indicate a lack of rare variants caused by rapid population expansion followed by a bottleneck or founder event (Schneider and Excoffier 1999). However Fu and Li's $D^{*}$ and Fu's $F_{s}$ tests are better at detecting background selection events, with Fu's $F_{\mathrm{s}}$ being the most sensitive of the two (Fu and Li 1993, Fu 1997) and Tajima's D better at detecting complete selective sweeps (Mousset et al. 2004). Finally, the $R_{2}$ statistic is the most powerful at identifying deviations caused by rapid population expansion with lower numbers consistent with recent explosive population growth (Ramos-Onsins and Rozas 2002, Sano and Tachida 2005). Ninetyfive percent confidence limit interval test-statistics were calculated for all neutrality tests in DNASP using a simulated coalescent process. 


\section{RESULTS}

Genetic Variation and Phylogeny

Of the 567 basepair nucleotide sequence data from the mtDNA control region (portions of domains I and II), 30 polymorphic sites were identified in the 91 Spotted Owls sampled in California with 17 of these sites shared between the two subspecies. The California Spotted Owl had 10 polymorphic sites, five unique to the subspecies, whereas the Northern Spotted Owl had 24 polymorphic sites, seven restricted to the Northern subspecies. In the haplotype sequences there was only a single fixed difference found between the two subspecies and all point mutations were characterized as transitional single base substitutions. There were no transversions, insertions, or deletions observed. Nucleotide $(\pi)$ and haplotype diversity $(h)$ indices were calculated separately for each population and each subspecies (Table 1). Both the Northern Spotted Owl subspecies $(\pi=0.00752)$ and the two individual populations had higher nucleotide diversity indices than the California Spotted Owl subspecies $(\pi=0.00196)$ and individual populations (Table 1). Mendocino had the highest nucleotide diversity at 0.01010 , whereas Monterey had none detected.

The phylogenetic analysis displayed two distinct branches or clades, with very high internal node bootstrap support values (96), consistent with the currently recognized subspecies designations (Fig. 3). A total of 17 haplotypes were identified amongst the two subspecies from the four locations (Table 2). A single haplotype was shared, and two of the Northern haplotypes were identified as more California-like in nature as they 
Table 1. Estimates of mitochondrial DNA control region variability within each regional population and subspecies: number of individuals $(n)$, number of haplotypes $(n h)$, nucleotide diversity $(\pi)$, haplotype diversity $(h)$, and mean number of pairwise differences $(M P D)$.

\begin{tabular}{|l|c|c|c|c|c|}
\hline $\begin{array}{l}\text { Locale/ } \\
\text { subspecies }\end{array}$ & $n$ & $n h$ & $\pi$ & $h$ & MPD \\
\hline $\begin{array}{l}\text { Marin } \\
\text { NSO }\end{array}$ & 23 & 3 & $\begin{array}{c}0.00347 \\
( \pm 0.00227)\end{array}$ & $\begin{array}{c}0.6403 \\
( \pm 0.0651)\end{array}$ & $\begin{array}{c}1.9684 \\
( \pm 1.1554)\end{array}$ \\
\hline $\begin{array}{l}\text { Mendocino } \\
\text { NSO }\end{array}$ & 25 & 8 & $\begin{array}{c}0.01010 \\
( \pm 0.00558)\end{array}$ & $\begin{array}{c}0.7733 \\
( \pm 0.0620)\end{array}$ & $\begin{array}{c}5.7267 \\
( \pm 2.8376)\end{array}$ \\
\hline $\begin{array}{l}\text { El Dorado } \\
\text { CSO }\end{array}$ & 28 & 8 & $\begin{array}{c}0.00280 \\
( \pm 0.00191)\end{array}$ & $\begin{array}{c}0.6534 \\
( \pm 0.0913)\end{array}$ & $\begin{array}{c}1.5900 \\
( \pm 0.9735)\end{array}$ \\
\hline $\begin{array}{l}\text { Monterey } \\
\text { CSO }\end{array}$ & 15 & 1 & 0.0000 & 0.0000 & 0.0000 \\
\hline All NSO & 48 & 10 & 0.00752 & $\begin{array}{c}0.8150 \\
( \pm 0.0010)\end{array}$ & 4.264 \\
\hline All CSO & 43 & 8 & 0.00196 & $\begin{array}{c}0.4730 \\
( \pm 0.0082)\end{array}$ & 1.114 \\
\hline
\end{tabular}

clustered in the California Spotted Owl clade of the neighbor-joining tree (Fig. 3). The single shared haplotype was the most common California haplotype found, the only haplotype in the Monterey population, and was identified in only a single Northern Spotted Owl from Mendocino. Seven of the 17 haplotypes were found exclusively in the California Spotted Owls and nine haplotypes were unique to the Northern Spotted Owl subspecies (Fig. 4). The haplotype diversities (h) were much greater in the Northern subspecies $(h=0.815)$ than the California subspecies $(h=0.473)$ (Table 1). The Mendocino population had the most individual diversity. El Dorado and Marin had similar haplotype diversities (Table 1) despite the El Dorado population having eight different haplotypes and Marin having only three haplotypes. However five of the eight haplotypes in El Dorado occurred as singletons, single individuals in a population with a 


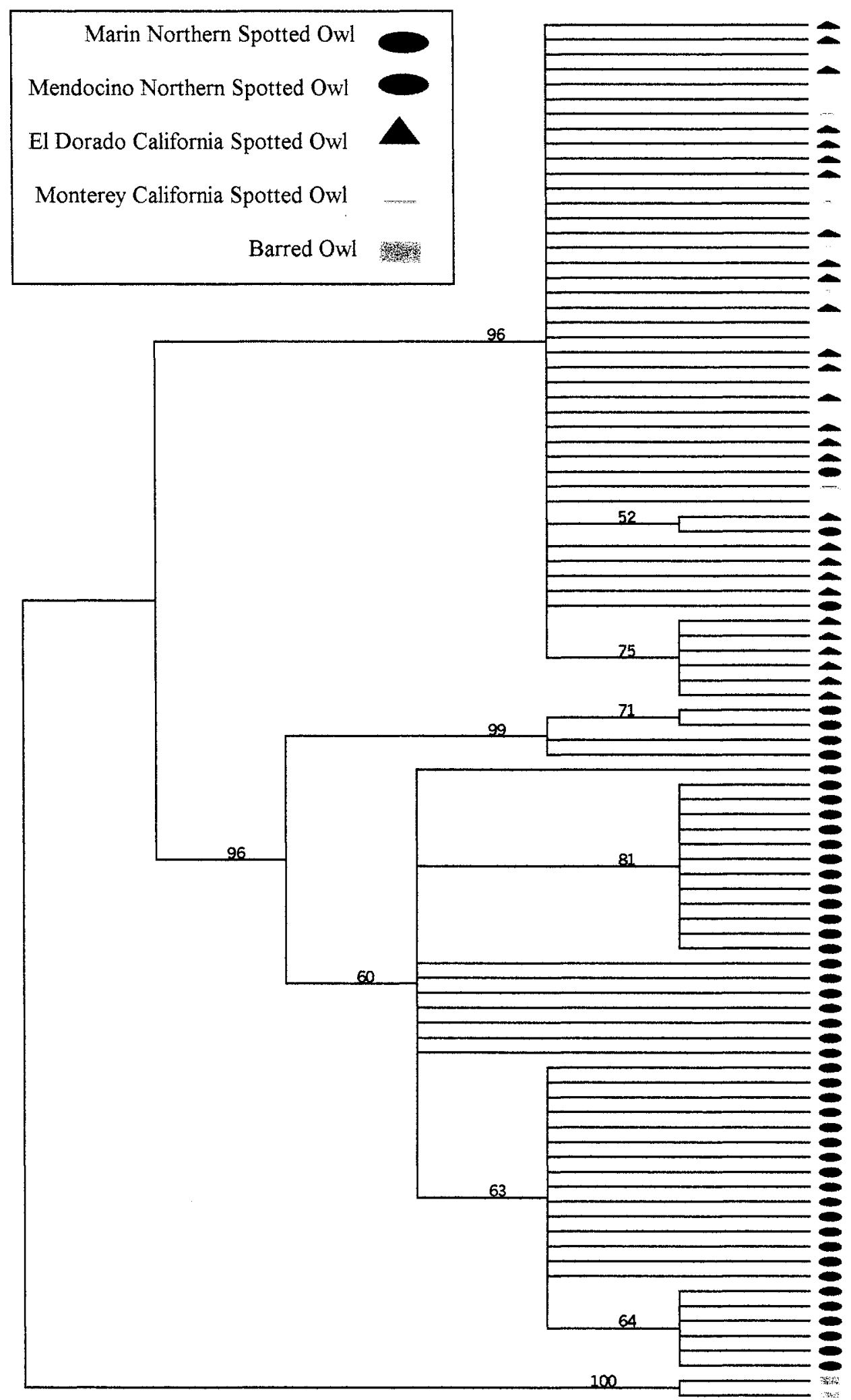

Figure 3. Kimura 2-Parameter Neighbor-Joining Tree with Bootstrap values. 


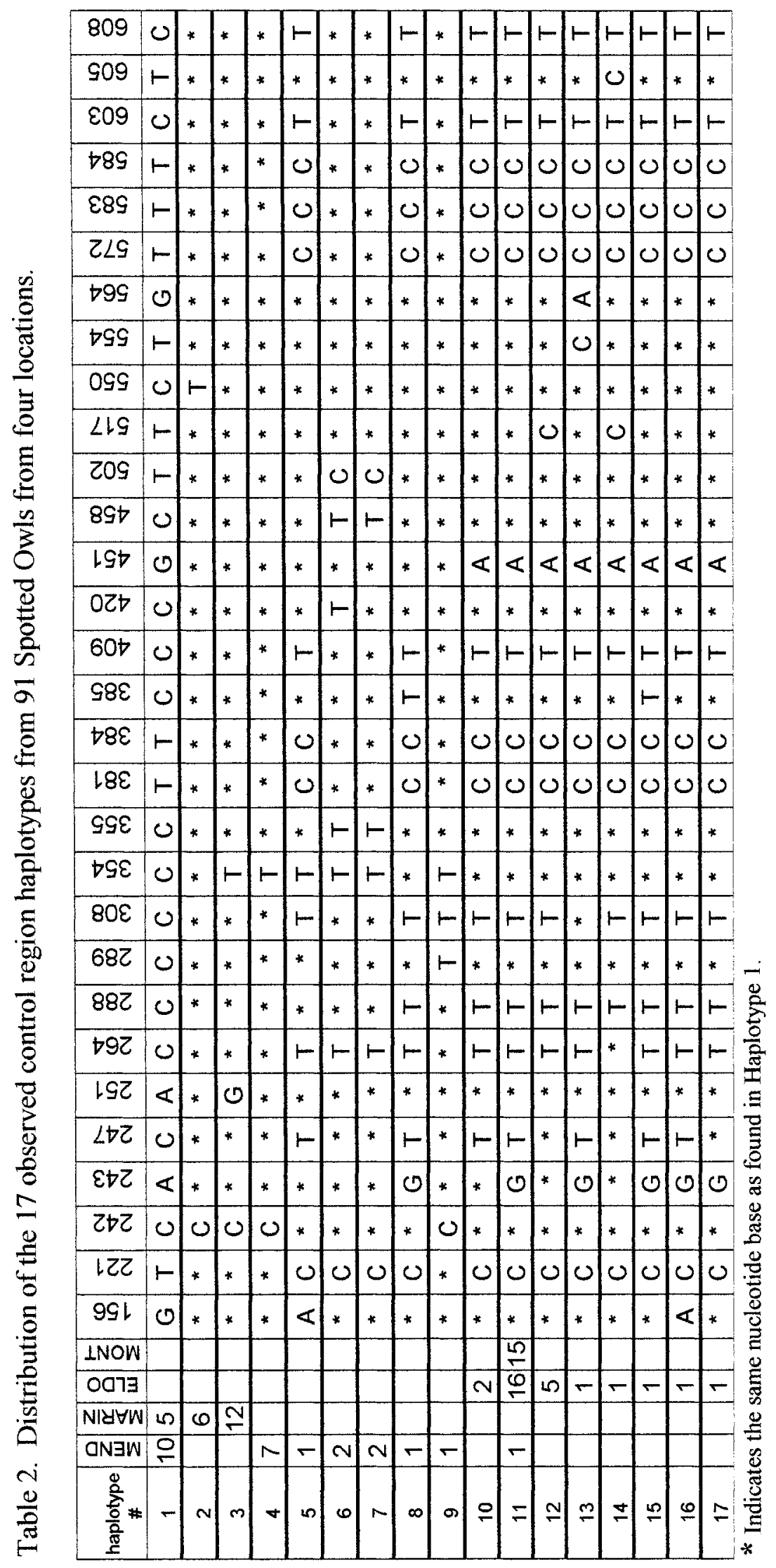



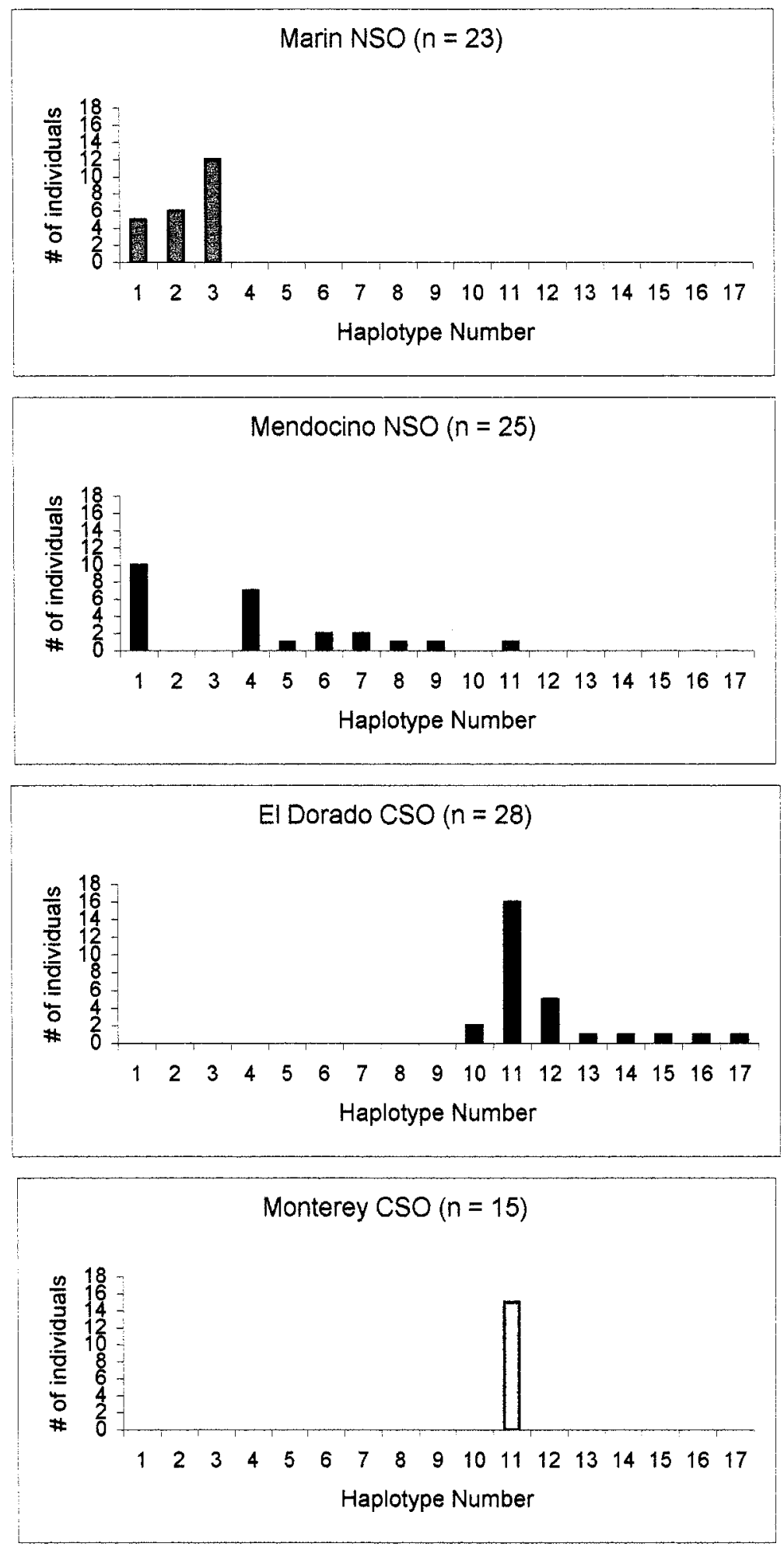

Figure 4. Haplotype frequencies for four populations of Spotted Owls. 
unique haplotype, whereas all the Marin haplotypes were more equally distributed throughout the population (Fig. 4). In contrast Mendocino had more haplotypes and higher haplotype diversity when compared to Marin, despite the presence of four singletons of the eight haplotypes. Seven of the 17 haplotypes identified were novel sequences.

In the hierarchical analysis of molecular variance most of the variance ( $81 \%)$ was between the two subspecies, rather than among populations within the subspecies $(2.7 \%)$ (Table 3). F-statistic fixation indices found the highest amount of genetic differentiation to be between subspecies $\left(F_{S T}=0.8374\right)$ and within all populations $\left(F_{C T}=0.8106\right)$, with very little differentiation found within each subspecies $\left(\mathrm{F}_{\mathrm{sc}}=0.1412\right)($ Table 3$)$.

Table 3. Analysis of molecular variance (AMOVA) of California and Northern Spotted Owls.

\begin{tabular}{|l|c|c|c|}
\hline \multicolumn{1}{|c|}{ Source of variation } & $\%$ variance & F-statistic & P-value \\
\hline Between subspecies & 81.06 & $F_{\mathrm{ST}}=0.83736$ & $<0.0001$ \\
\hline Among populations within subspecies & 2.68 & $\mathrm{~F}_{\mathrm{SC}}=0.14125$ & $<0.0001$ \\
\hline Between all individuals & 16.26 & $\mathrm{~F}_{\mathrm{CT}}=0.81061$ & 0.34656 \\
\hline
\end{tabular}

Pairwise comparisons between each population showed the biggest differences between populations of the different subspecies: Marin and Monterey (15.8\%), followed by El Dorado and Marin (14.8\%), Mendocino and Monterey (12.0\%), and El Dorado and Mendocino (11.2\%) (Table 4). The coastal populations of each subspecies were both subsets of their inland counterpart populations and, therefore, had small pairwise differences: Marin and Mendocino (0.7\%), Monterey and El Dorado $(0.2 \%)$. 
Table 4. Spotted Owl Population pairwise $\mathrm{F}_{\text {ST }}$ values (below diagonal), average pairwise differences within each population (diagonal), average pairwise differences between populations (above diagonal).

\begin{tabular}{lllll}
\hline & $\begin{array}{l}\text { El Dorado } \\
\text { (CSO) }\end{array}$ & $\begin{array}{l}\text { Monterey } \\
\text { (CSO) }\end{array}$ & $\begin{array}{l}\text { Mendocino } \\
\text { (NSO) }\end{array}$ & $\begin{array}{l}\text { Marin } \\
\text { (NSO) }\end{array}$ \\
\hline El Dorado (CSO) & 1.58995 & 0.16931 & 11.18596 & 14.82487 \\
Monterey (CSO) & 0.12098 & 0.00000 & 12.01667 & 15.79842 \\
Mendocino (NSO) & 0.75993 & 0.76748 & 5.27667 & 0.66378 \\
Marin (NSO) & 0.89390 & 0.92915 & 0.14327 & 1.96838 \\
\hline
\end{tabular}

Within each subspecies the connected inland populations had much higher diversity as indicated by a variety of haplotypes, when compared to each isolated counterpart coastal population. The mean pairwise differences among individuals within each population were found to be largest in the Northern Spotted Owl Mendocino population (5.73) (Table 1). The Marin population had a much lower value (1.97) due to the presence of only three haplotypes differing from one another at only one or two nucleotide positions. The California Spotted Owl El Dorado average pairwise differences (1.59) were slightly lower than that of Marin, and there were no differences found in Monterey where only one haplotype was present.

Historic Population Demography

Histograms of mismatch distributions (Fig. 5) determined by pairwise differences were performed on the three polymorphic populations (excluding Monterey) to evaluate 
the likelihood of rapid changes in homogenous populations (Rogers and Harpending 1992). Histograms of all three populations expressed ragged multimodal pairwise
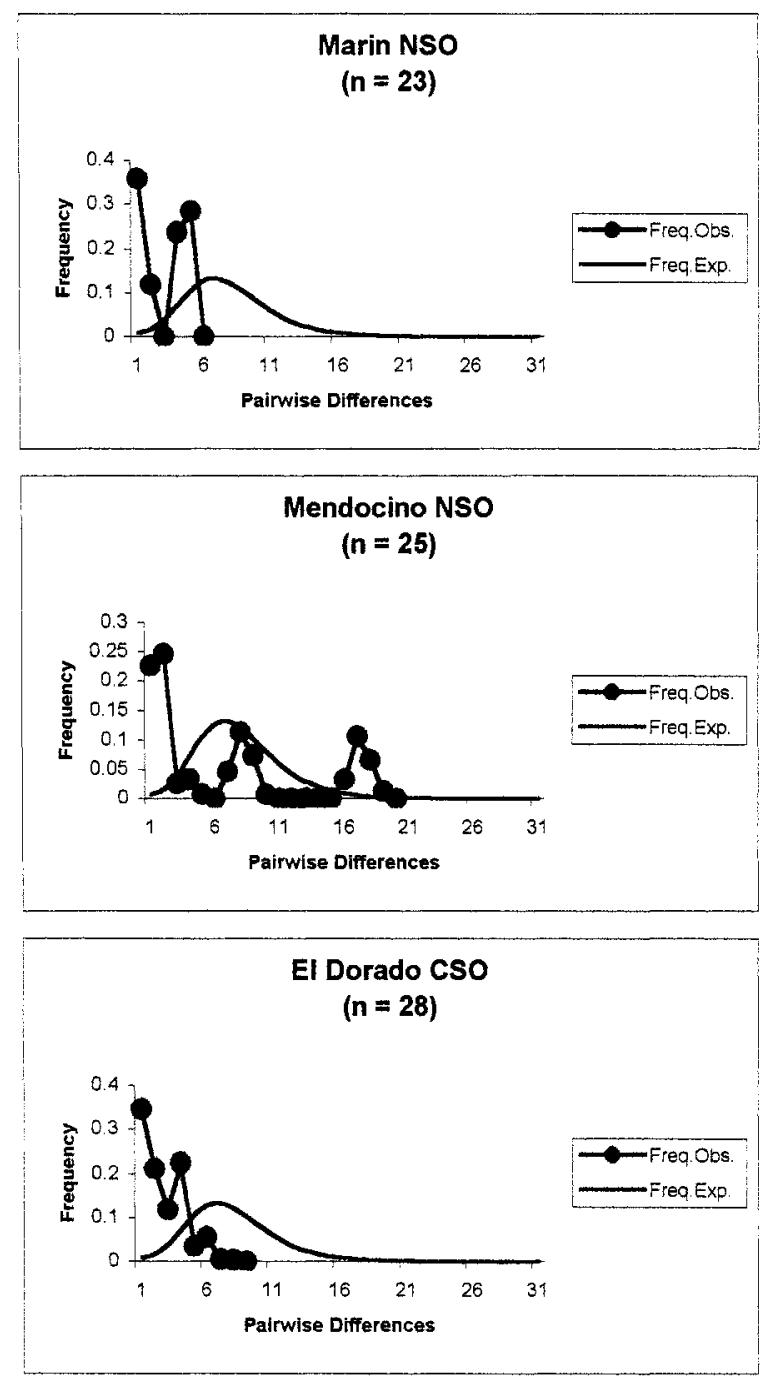

Figure 5. Mismatch distributions for three populations of Spotted Owls.

differences with high frequency peaks located at zero. Additional peaks were observed at varying locations based upon the population. Computer generated prediction expansion models for each of the populations had smooth unimodal peaks estimated at about six pairwise differences. All Harpending raggedness values were greater than 0.06 (Table 
5), signifying stationary population sizes, and were in agreement with mismatch distributions.

In specified neutrality tests statistically significant values were obtained for Marin Northern Spotted Owl and El Dorado California Spotted Owl populations (Table 5). Within the panel of neutrality tests Marin displayed statistically significant values of Tajima's D (2.261), Fu and Li's F* (1.6413), Fu and Li's D* (1.0898), Fu's F $F_{s}(3.404)$, and the $R_{2}$ statistic (0.2460) indicating a scarcity of rare haplotypes. Although the El Dorado population had only two statistically significant values: Fu and Li's F* (-2.0222) and $\mathrm{Fu}$ and $\mathrm{Li}$ 's $\mathrm{D}^{*}(-2.0561)$, all neutrality tests (except $\mathrm{R}_{2}$ statistic) yielded negative values which indicate an excess of rare haplotypes. None of the neutrality tests for Mendocino indicated atypical results deviating from evolutionary neutrality. The single haplotype found in the Monterey population, did not allow for the application of any neutrality tests (Table 5). 
Table 5. Neutrality control region statistics within each regional population: Tajima's D (TD), Fu and Li's F* (no outgroup), Fu and Li's F (Barred Owl outgroup), Fu and Li's D* (no outgroup), Fu and Li's D (Barred Owl outgroup), $\mathrm{Fu}^{\prime} \mathrm{F}_{\mathrm{s}}$, Harpending's raggedness index (Hri).

\begin{tabular}{|l|c|l|c|c|c|c|c|c|c|}
\hline $\begin{array}{l}\text { Locale/ } \\
\text { subspecies }\end{array}$ & $n$ & TD & Fu\&Li F* & Fu\&Li F & $\begin{array}{l}\text { Fu\&Li } \\
D^{*}\end{array}$ & Fu\&Li D & Fu'sF & Hri & $\mathrm{R}_{2}$ \\
\hline $\begin{array}{l}\text { Marin } \\
\text { NSO }\end{array}$ & 23 & $2.2611^{\mathrm{a}}$ & $1.6413^{\mathrm{a}}$ & 1.6959 & $1.0898^{\mathrm{ad}}$ & 1.1116 & $3.4035^{\text {ad }}$ & 0.2117 & $0.2460^{\mathrm{b}}$ \\
\hline $\begin{array}{l}\text { Mendocino } \\
\text { NSO }\end{array}$ & 25 & -0.3639 & 0.3959 & 0.6455 & 0.6529 & 0.9880 & 1.9693 & 0.0734 & 0.1137 \\
\hline $\begin{array}{l}\text { El Dorado } \\
\text { CSO }\end{array}$ & 28 & -0.9868 & $-2.0222^{\mathrm{a}}$ & -2.2652 & $-2.0561^{\mathrm{ac}}$ & -2.3183 & -2.2424 & 0.0772 & 0.0895 \\
\hline $\begin{array}{l}\text { Monterey } \\
\text { CSO }\end{array}$ & 15 & - & - & - & - & - & - & - & - \\
\hline
\end{tabular}

${ }^{a}$ statistically significant value $\mathrm{P}<0.05$

${ }^{\mathrm{b}}$ statistically significant value $\mathrm{P}<0.01$

${ }^{c}$ statistically significant when using theta for the simulations, but not when using number of segregating sites.

${ }^{d}$ statistically significant when using number of segregating sites for the simulations, but not when using theta. 


\section{DISCUSSION}

\section{Mitochondrial DNA Population Structure}

This phylogenetic analysis indicated a deep split between the Northern and California Spotted Owl subspecies; only one haplotype was shared and it was found in a single Northern Spotted Owl. Finding two distinct clades with high bootstrap values (> $95 \%$ ) supports the findings of earlier studies (Barrowclough et al. 1999, Haig et al. 2004a, Barrowclough et al. 2005). These suggest extremely limited gene flow and support current subspecies designations and sampled ranges.

Much more genetic structure was displayed in the Northern subspecies as indicated by the higher nucleotide and haplotype diversities. The Mendocino National Forest population is located at the southern end of the contiguous suitable habitat range of the Northern Spotted Owl and was the most genetically diverse of the four sampled populations with no apparent gene flow barriers between it and neighboring demes. It had nucleotide diversity $(0.0101 \pm 0.0056)$ comparable to the high values found in the overall Northern Spotted Owl subspecies $(0.0114 \pm 0.0060)$ and Klamath region populations $(0.0142 \pm 0.0074)$ by Haig et al. (2004a). All are slightly higher than those reported by Barrowclough et al. (1999 and 2005) for combined Humboldt, Trinity, Del Norte, and Siskiyou Counties (0.0068), possibly due to differences in sampling sizes used.

The Marin population is essentially located on a coastal peninsula, at the southernmost tip of the Northern Spotted Owl geographic range and displayed island-like characteristics, separated from other owls by $120 \mathrm{~km}$ of generally unsuitable habitat to 
the north and the San Francisco Bay to the south. The neutrality tests of Tajima's D and Fu's $F_{s}$ produced significant values that were large and positive. Both values indicate a lack of rare haplotypes and are common in populations produced by a bottleneck or founder event (Fu 1997, Schneider and Excoffier 1999). Although a high value for Tajima's D has been used to indicate a rapid expansion following such an event (Schneider and Excoffier 1999), the high $\mathrm{R}_{2}$ statistic is a more powerful test and suggested a gradual population growth. Based upon the geographic limitations, lack of rare variants, low nucleotide diversity $(0.0035 \pm 0.0022)$, and haplotype $(0.6403 \pm$ 0.0651 ) diversity, this genetic pattern is likely the result of a relatively recent, small founder population peripatric to the central range. With relatively equal numbers of a few haplotypes, this appeared to be a population segment nearing equilibrium as was also indicated by the microsatellite analysis displaying an excess of heterozygotes (Henke 2005). Both microsatellite and mitochondrial markers indicated a lack of contemporary contact with the closest genetic sources found to the north.

The California Spotted Owl had considerably less genetic variability in nucleotide diversity $(0.00196)$ than its Northern relative $(0.00752)$, with no detected variability in the Monterey population (Table 1). The El Dorado population is located in the central Sierra Nevada Mountains, in the middle of the recognized subspecies range. Considering the seemingly contiguous habitat north and south of the El Dorado population, there was a surprisingly low genetic diversity, with one predominant haplotype (57\%) and five of the other seven haplotypes were singletons not found in any previous studies of California Spotted Owls. The haplotype frequency distribution and the low nucleotide 
diversity were similar to those values reported in the Fresno $(0.0025 \pm 0.0019)$ and Lassen $(0.0017 \pm 0.0014)$ populations by Haig et al. (2004a) and the E1 Dorado ( $0.0016)$ and Sequoia $(\sim 0.0016)$ populations of Barrowclough et al. $(1999,2005)$. The Lassen California Spotted Owl population was also found to have low nucleotide diversity $(\sim 0.0007)$ by Barrowclough et al. (1999); however, considerably higher nucleotide diversity (between 0.006 and 0.007 ) was reported in the most recent Barrowclough et al. (2005) study. The recent finding was possibly due to the influence of sampling the introgression zone of the California and Northern subspecies where the mixing of haplotypes might increase the nucleotide diversity. It could also be a direct result of a higher sample size in the more recent study (eleven vs. five individuals).

The El Dorado population, although statistically significant for only two of the neutrality tests, had negative values for all of the tests, which are indicative of an excess of low frequency haplotypes. El Dorado had the lowest $\mathrm{R}_{2}$ statistic value of all three polymorphic populations $(0.0895)$ indicating a more rapid historic population expansion than any of the other populations (Table 5). The Fu and $\mathrm{Li} \mathrm{F}^{*}$ and $\mathrm{D}^{*}$ tests were significant (using a Barred Owl sequence as the outgroup), and take into account the number of singletons in the sequence pairwise comparisons, making them more sensitive than other neutrality tests to background selection (Fu and Li 1993, Fu 1997). Fu (1997) suggested the Fu's $\mathrm{F}$ is better for non-recombining markers at detecting population growth and genetic hitchhiking while Fu and Li's (1993) tests are better at picking up background selection. When all of the El Dorado data in this study were combined with the Lassen and Sequoia populations of Barrowclough et al. (2005), the neutrality tests 
found statistically significant deviations from $\mathrm{Fu}$ and $\mathrm{Li} \mathrm{F}, \mathrm{F}^{*}, \mathrm{D}^{*}$ and $\mathrm{D}$ neutrality models. In neither this study, Barrowclough et al. (1999 and 2005), or Haig et al. (2004a) were significant deviations found from Tajima's D neutrality tests, possibly due to a small sample size (Simonsen et al. 1995). None of the other studies included results of any additional neutrality test.

Populations out of equilibrium that have an excess of rare haplotypes are consistent with an expanding population ( $\mathrm{Fu}$ and $\mathrm{Li} 1993)$ and also populations recovering from a historic bottleneck (Tajima 1989a and1989b). However, the Harpending's Raggedness value and mismatch distribution do not support expanding populations, and a bottleneck was not detected for El Dorado by the analysis of microsatellite markers (Henke 2005). In fact, the microsatellite marker global locus analysis of Hardy-Weinberg equilibrium revealed an excess of homozygotes (Henke 2005) often common to inbreeding or subpopulation fragmentation. This agreed with significant $\mathrm{Fu}$ and $\mathrm{Li} \mathrm{F*}$ and $\mathrm{D}^{*}$ values in my study and was consistent with populations experiencing background selection events (Fu and Li 1993), bottlenecks, hitchhiking, and/or subdivision. It is possible that historic background selection events have occurred to the control region since it is linked to the entire mitochondrial genome; however, it is more likely that subdivision has been detected by both the microsatellites and mitochondrial DNA analysis. The mitochondrial neutrality test results, the microsatellite analysis, the lack of information regarding contiguous owl territories throughout the range (except on Federal land), and the most recent California Spotted Owl meta-analysis 
indicating declining population trends (Franklin et al. 2004), suggest that subpopulation fragmentation and inbreeding are possibilities and concerns.

The Monterey population is at the northern end of the coastal range of the California Spotted Owl, separated from Sierra owls by the Central Valley to the east, and south coastal owls by a fragmented chain of populations to the south, thus leaving this population considerably isolated to potential gene flow. This group had alarmingly low amounts of variation indicated by a single monomorphic haplotype in this study $(\mathrm{n}=15)$ and very low microsatellite polymorphism, with two out of six loci fixed (Henke 2005). However, Barrowclough et al. (1999 and 2005) also found this same haplotype in all individuals $(n=48)$ from the populations of Carmel and all southern California Spotted Owls located in San Bernadino, San Jacinto, and Palomar. There are several possible explanations for the lack of genetic variability in the 63 sampled owls found throughout the coast range. This could be the result of a recent bottleneck or a small founder population that has reached fixation. It is also possible that these populations have undergone some type of genetic hitchhiking or selective sweep. Although the control region has been considered a neutral/noncoding sequence, there are important genes coded for in the mitochondrial genome and lack of recombination mechanisms could theoretically influence success and survival of specific haplotypes. In order to develop a more extensive understanding of the interrelationships within these coastal populations the use of microsatellites or some other type of marker should be employed. Regardless of the cause in the lack of haplotype variation it is apparent that these southern and coastal populations are genetically impoverished and likely more vulnerable to extinction 
risks due to habitat changes, disease, competition, or other conditions possibly requiring new adaptations.

Inferring Historic Relationships

Comparisons between subspecies populations using an AMOVA indicated an Fst value of $0.8374(\mathrm{P}<0.0001)$ and a total variance of $81.09 \%$ (Table 3$)$ meeting the suggested $75 \%$ difference in a single character analysis for a subspecies division (Patten and Unitt 2002). However, there is strong evidence some gene flow has occurred between the subspecies as indicated in both this mitochondrial DNA study and Henke's (2005) microsatellite analyses. Evidence was found in a single California mitochondrial haplotype and two California-like haplotypes (clustering in the California Spotted Owl branch of the phylogenetic tree) located in the Mendocino National Forest Northern Spotted Owl range. It is unlikely that migration between the sites has recently occurred due to the wide geographic barrier (either up and around or across the Central Valley) between these two subspecies populations and the lack of identical haplotypes in the two sampled California Spotted Owl populations. It is more plausible that these haplotypes are relicts of ancient gene flow. The lack of Northern Spotted Owl haplotypes in the two California Spotted Owl populations is also consistent with results of range wide California Spotted Owl mitochondrial studies (Barrowclough et al. 1999 and 2005, and Haig et al. 2004a). These mtDNA results suggest a historic directional flow from the California subspecies to the Northern range. However, the origin of ancestry cannot be conclusively determined by these data. Microsatellite analysis in the El Dorado 
population did show mixing of Northern Spotted Owl alleles in some of the California Spotted Owls (Henke 2005) and suggested that gene flow, although limited, may have been bidirectional in recent history.

Haig et al. (2004a) suggested that owls in the Northern Spotted Owl range retaining California or California-like haplotypes were California Spotted Owls (see Table 1 of Haig et al. 2004a). This conclusion would be premature without the integration of nuclear markers from a biparental descent to support this result. It is very possible that these are ancestral artifact haplotypes and the nuclear markers might clarify the true history. The Shasta-Lassen zone between the two subspecies may have been a gradational transition zone historically, but due to past geologic events the interim populations may have been destroyed. Mount Shasta erupted as recently as 1786 and Mount Lassen sporadically from 1914 to 1917 (Schoenherr 1992, Clynne et al. 1999). The repercussions that one or more eruptions might have on the immediate region and on surrounding habitat could be enough to have a profound effect on Spotted Owl genetics and act as a more recent barrier to dispersal. In addition, glacial retreats and advances during the Pleistocene (Hilton and Lydon 1976, Kane 1982, Guyton 1998), may have affected the phylogeography. Some insight into these questions might be gained by further genetic assessment of the region where potential mixing of subspecies and their neighboring populations occur, employing nuclear DNA as markers to determine the nature of the relationships between the subspecies. There did appear to be a substantial amount of mitochondrial DNA genetic structure within the Northern Spotted Owls, possibly indicative of an evolutionarily older population (Haig et al. 2004a). However, 
the shallower structure of California Spotted Owls could be a direct result of a historic bottleneck in the California subspecies in which this mitochondrial DNA marker may not be sensitive enough to decipher.

Limitations of Genetic Analysis

Although genetic analysis can be a very powerful tool for understanding historic and current relationships, one should be cautious forming conclusions based on these data alone as they may not reveal contemporary gene flow patterns but may instead represent historic evolutionary trends or episodes (Avise 2004). A potential for bias is also possible based upon the type of marker used and mechanism of inheritance (Mendelian, haploid, occurrence of recombination, linkage). A more accurate and complete understanding of true events may emerge with the use of a greater variety of molecular markers, each one capable of addressing different questions regarding relationships and structure. Genetic information should also be integrated with all aspects of known Spotted Owl behavior and biology.

The mitochondrial DNA genome codes for several crucial components in the metabolic process of energy synthesis where their combined functions act as electron transport pathways responsible for transfer and removal of harmful reactive oxygen species from the mitochondria. Abnormal functioning of any one of these gene complexes (ND1, ND2, ND3, ND4, ND5, ND6, Cox1, Cox2, Cox3, ATP6, ATP8, and Cyt b) could clearly impact the physiological response within the cell (Alexeyev et al. 2004, Ballard and Whitlock 2004). Therefore despite the assumed neutrality of the 
control region, it is possible that selection could be taking place upon some other portion within the mitochondrial genome, and thus the marker as a whole could be vulnerable to selective mechanisms. 


\section{MANAGEMENT IMPLICATIONS}

Although the Northern Spotted Owl and Mexican Spotted Owl subspecies have received protection by the Federal Endangered Species Act since 1990 and 1993 (respectively), listing of the California Spotted Owl has been denied twice. Although it has been difficult to determine accurate population estimates, Gutiérrez et al. (1995) suggested California Spotted Owl numbers about one-fourth that of Northern Spotted Owls. The most recent results in an extensive meta-population study of five Sierra California Spotted Owl populations indicated the likelihood of declining population trends and advised a management approach erring on the side of caution (Franklin et al. 2004). Genetic examination has indicated the California Spotted Owl has the most limited genetic variability of all three subspecies (Barrowclough et al. 1999, Haig et al. 2004a, Barrowclough et al. 2005, Henke 2005) and that of the coastal population, which could be considered a separate ESU, is extremely low. The California Spotted Owl's impoverished genetic pool, low population estimates, and more recently the lack of habitat protection by changes made to the Sierra Nevada Framework, are all indicators of a subspecies that requires additional recognition and protection by the Federal Government under the Endangered Species Act. 


\section{LITERATURE CITED}

AvISE, J. C. 2004. Molecular Markers, Natural History, and Evolution. $2^{\text {nd }}$ ed. Sinauer Associates, Sunderland, Maryland.

AleXeYeV, M. F., S. P. LeDouX, AND G. L. WILSON. 2004. Mitochondrial DNA and aging. Clinical Science 107:355-364.

BAKeR, A. J. AND H. D. MARShall. 1997. Avian Molecular Evolution and Systematics, p. 58. Academic Press, San Diego, California.

BALLARD, J. W. O. AND M. C. WHITLOCK. 2004. The incomplete natural history of mitochondria. Molecular Ecology 13:729-744.

BARROWCLOUGH, G. F. AND R. J. GUTIÉRREZ. 1990. Genetic variation and differentiation in the Spotted Owl (Strix occidentalis). Auk 107:737-744.

BARROWCLOUGH, G. F., R. J. GUTIÉRREZ, AND J. G. GROTH. 1999. Phylogeography of Spotted Owl (Strix occidentalis) populations based on mitochondrial DNA sequences: gene flow, genetic structure, and a novel biogeographic pattern. Evolution 53:919-931.

BARROWCLOUGH, G. F., J. G. GROTH, L. A. MERTZ, AND R. J. GUTIÉRREZ. 2005. Genetic structure, introgression, and a narrow hybrid zone between Northern and California Spotted Owls (Strix occidentalis). Molecular Ecology 14:1109-1120.

Clynne, M. A., Christiansen, R. L., Felger, T. J., Stauffer, P. H., ANd Hendley II, J. W. 1999. Eruptions of Lassen Peak, California, 1914 to 1917: U. S. Geological Survey Fact Sheet 173-98.

Forsman, E. D., C. MESLOW, AND H. Wright 1984. Distribution and biology of the Spotted Owl in Oregon. Wildlife Monographs 87:1-64.

Frankin, A. B., R. J. GutiérRez, J. D. Nichols, M. E. Seamans, G. C. White, G. S. Zimmerman, J. E. Hines, T. E. Munton, W. S. LaHaye, J. A. Blakesley, G. N. StegER, B. R. NoON, D. W. H. ShaW, J. J. KeANe, T. L. MCDONAld, AND S. BRITting. 2004. Population dynamics of the California Spotted Owl (Strix occidentalis occidentalis): a meta-analysis. Ornithological Monographs 54:1-54.

FU, Y-X. 1996. New statistical tests of neutrality for DNA samples from a population. Genetics 143:557-570.

FU, Y-X. 1997. Statistical tests of neutrality of mutations against population growth, hitchhiking and background selection. Genetics 147:915-925. 
FU, Y-X. AND W-H. LI. 1993. Statistical tests of neutrality of mutations. Genetics 133:693- 709 .

GRIFFITHS, R., M.C. Double, K. ORR, AND R.G WILSON. 1998. A DNA test to sex most birds. Molecular Ecology 7:1071- 1075.

Gutiérrez, R. J., A. B. Franklin, AND W. S. LAHAYE. 1995. Spotted Owl (Strix occidentalis). In The Birds of North America, no. 179. (A. Poole and F. Gill, Eds.). Academy of Natural Sciences, Philadelphia, and American Ornithologists' Union, Washington, D. C.

GuYTon B. 1998. Glaciers of California. University of California Press, Berkeley and Los Angeles, California pp 88-89.

Haig, S. M., R. S. Wagner, E. D. Forsman, AND T. D. Mullins. 2001. Geographic variation and genetic structure in Spotted Owls. Conservation Genetics 2:25-40.

Haig, S. M., T. D. Mullins, AND E. D. Forsman. 2004a. Subspecific relationships and genetic structure in the Spotted Owl. Conservation Genetics 5:683-705.

Haig, S. M., T. D. Mullins, E. D. Forsman, P.W. Trail, And L. Wennerberg. 2004b. Genetic identification of Spotted Owls, Barred Owls, and their hybrids: legal implications of hybrid identity. Conservation Biology 18:1347-1357.

HARPENDING, H. C. 1994. Signature of ancient population growth in a low-resolution mitochondrial DNA mismatch distribution. Human Biology 66:591-600.

HARPENDING, H. C., S. T. SherRY, A.R. Rogers, AND M. StONEKING. 1993. The genetic structure of ancient human populations. Current Anthropology 34:483-496.

HENKE, A. L. 2005. Spotted Owls (Strix occidentalis) microsatellite variation in California. M.Sc. thesis, San José State University, San José, CA.

Kumar, S., K. TAMURA, I. G. JAKOBSEN, AND M. NEI. 2001. MEGA2: molecular evolutionary genetics analysis software. Bioinformatics 17:1244-1245.

MARSHALL, D. H. AND A. J. BAKER. 1997. Avian Molecular Evolution and Systematics. Academic Press, San Diego, California pp 51-79.

MARSHALL, D. H. AND A. J. BAKER. 1997. Structural conservation and variation in the mitochondrial control region of Fringilline Finches (Fringilla spp.) and the Greenfinch (Carduelis chloris). Molecular Biology and Evolution 14:173-184. 
MOUSSET, S., N. DEROME, AND M. VeUILLE. 2004. A test of neutrality and constant population size based on the mismatch distribution. Molecular Biology and Evolution 21:724-731.

PATtON, M.A. AND P. UNITT. 2002. Diagnosability versus mean differences of Sage Sparrow subspecies. Auk 119:26-35.

PyLe P. 1997. Identification Guide to North American Birds. Part I Columbidae to Ploceidae. Slate Creek Press, Bolinas, CA.

RAMOS-ONSINS, S. AND J. ROZAS. 2002. Statistical properties of new neutrality tests against population growth. Molecular Biology and Evolution 19:2092-2100.

REMSEN, J. V. 1978. Bird species of special concern in California: An annotated list of declining or vulnerable bird species. Nongame Wildl. Invest., Wildl. Mgmt. Branch Admin. Rept. 78-1. Calif. Dept. Fish \& Game, 1416 Ninth St., Sacramento, CA 95814.

ROGERS, A.R AND H. HARPENDING. 1992. Population growth makes waves in the distribution of pairwise genetic differences. Molecular Biology and Evolution 9:552-569.

Rozas, J., J.C. SANCheZ-Del BarRio, X. Messeguer, AND AND R. Rozas. 2003. DnaSP, DNA polymorphism analyses by the coalescent. Bioinformatics 19:2496-2497.

ROZAS, J. AND R. ROZAS. 1999. DnaSP version 3: an integrated program for molecular population genetics and molecular evolution analysis. Bioinformatics 15:174-175.

SANO, A. AND H. TACHIDA. 2005. Gene genealogy and properties of test statistics of neutrality under population growth. Genetics 169:1687-1697.

SCHNEIDER, S. AND L. EXCOFFIER. 1999. Estimation of past demographic parameters from the distribution of pairwise differences when the mutation rates vary among sites: application to human mitochondrial DNA. Genetics 152:1079-1089.

SCHNEIDER, S., D. ROESSLI, AND L. EXCOFFIER. 2000. Arlequin: a software for population genetics data analysis. Ver 2.000. Genetics and Niometry Lab, Department of Anthropology, University of Geneva, Geneva, Switzerland.

SCHOENHERR, A. 1992. A Natural History of California. University of California Press, Berkeley and Los Angeles, California pp 229-231, 234-235.

Simonsen, K. L., G. A. Churchill and C. F. AQuadro. 1995. Properties of statistical tests of neutrality for DNA polymorphism data. Genetics 141:413-429. 
SLATKIN, M. AND R.R. HudSON. 1991. Pairwise comparisons of mitochondrial DNA sequences in stable and exponentially growing populations. Genetics 129:555-562.

Smith, R. B., M. Z. Peery, R. J. Gutiérrez, AND W. S. LAHAye. 1999. The relationship between Spotted Owl diet and reproductive success in the San Bernadino mountains, California. Wilson Bulletin 111:22-29.

SWOFFORD, D. L. 2000. PAUP*. Phylogenetic analysis using parsimony (*and other methods). Version 4.0b2. Sinauer, Sunderland, MA.

TAJMA, F. 1989a. Statistical method for testing the neutral mutation hypothesis by DNA polymorphism. Genetics 123:585-595.

TAJIMA, F. 1989b. The effect of change in population size on DNA polymorphism. Genetics 123:597-601.

U.S. DEPARTMENT OF INTERIOR (USDI). 2003. Endangered and threatened wildlife and plants: 12-month finding for a petition to list the California Spotted Owl (Strix occidentalis occidentalis). Federal Register 68:7580-7608.

U.S. DEPARTMENT OF INTERIOR (USDI). 2006. Endangered and threatened wildlife and plants: 12-month finding for a petition to list the California Spotted Owl (Strix occidentalis occidentalis). Federal Register 71:29886-29908.

Young, K.E., P.J. Zwank, R. VALDEZ, J.L. DyE, AND L.A. TARANGo. 1997. Diet of Mexican Spotted Owls in Chihuahua and Aquascalientes, Mexico. Journal of Raptor Research 31:376-380. 